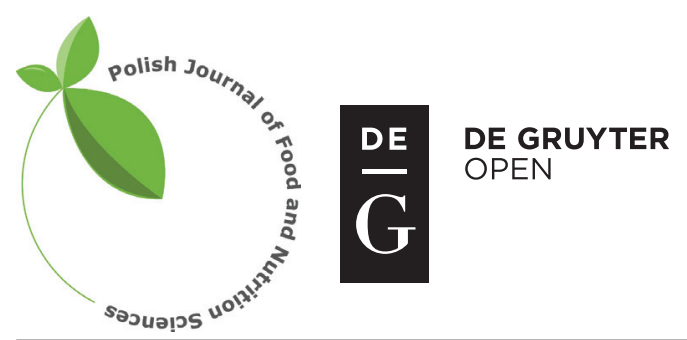

Pol. J. Food Nutr. Sci., 2017, Vol. 67, No. 1, pp. 49-58

DOI: $10.1515 /$ pjfns-2016-0018 http://journal.pan.olsztyn.pl

Original article

Section: Food Quality and Functionality

\title{
Influence of Sugars, Modified Starches and Hydrocolloids Addition on Colour and Thermal Properties of Raspberry Cream Fillings
}

\author{
Anita Pichler*, Andrija Pozderović, Tihomir Moslavac, Kristina Popović
}

\author{
Faculty of Food Technology, Josip Juraj Strossmayer University in Osijek, Franje Kuhača 20, 31000 Osijek, Croatia
}

Key words: raspberry cream fillings, additives, storage, colour, thermal properties

This paper deals with the influence of the addition of sugars (sucrose, fructose and trehalose), modified starches (tapioca or waxy maize starch) and hydrocolloids (karaya or guar gum) on colour and thermal properties of raspberry cream fillings. In addition, the influence of the above-mentioned additives on the colour and thermal properties of raspberry cream fillings stored at room temperature over a period of 8 and 16 months was investigated. Results showed that the highest anthocyanin content and total phenolic content were detected in raspberry cream filling prepared with sucrose and trehalose in combination with guar gum. During storage, after 8 and 16 months at room temperature, anthocyanin content and total phenolic content decreased. Results also showed that the kind of sugar and added modified starches or hydrocolloids influenced the thermal properties of cream fillings. During storage, a decrease was observed in both freezing temperature as well as enthalpy of cream fillings.

\section{INTRODUCTION}

Raspberry fruit is well recognised for health promoting constituents. There have been studies about the potential role of raspberries in preventing chronic stress, cancer and heart diseases [Zhang et al., 2005]. Since raspberries (Rubus idaeus) are very perishable fruit and to preserve its components that positively affect human health, it is used industrially for producing semi-products and products, like jam, jelly, sauce, puree, topping, syrup or juice concentrates. Colour is an important quality attribute of the food. In fact, colour is usually the first criterion in determining the acceptability of fruit products. Anthocyanins, a flavonoid group of pigments, are responsible for raspberries colour. They can contribute to the healthiness due to their antioxidant, anticarcinogenic, anti-inflammatory, and anti-angiogenic properties [Clifford, 2000; Kong et al., 2003; Rossi et al., 2003]. There are lots of factors that influence anthocyanin stability like $\mathrm{pH}$, storage temperature, enzymes, light, oxygen, the anthocyanins structure and concentration, as well as biologically-active ingredients (flavonoids, proteins, and minerals) [Rein, 2005]. Since they are extremely unstable and easily inclined to degradation, it is very important to achieve their stability in raspberry products, not just to save the colour, but also to save the possible health benefits. The objective of many studies was improvement of stability of anthocyanins through addition of different additives, like acids, sugars, salts and hydrocolloids [Wilska-Jeszka \& Korzuchows-

\footnotetext{
* Corresponding Author: Tel.: +385 312243 19;

E-mail: anita.pichler@ptfos.hr (Prof. A. Pichler)
}

ka, 1996; Boulton, 2001; Hubbermann et al., 2002, 2006; Bakowska et al., 2004; Mollov et al., 2007; Awika, 2008; Oszimański et al., 2009] that are commonly used as additives in the fruit industry for achieving desired properties. Generally, sugars and starches are important ingredients in many food products. Addition of sugar to starch-containing products can have effect on some starch properties (gelatinisation, retrogradation and staling). The proposed mechanisms for explanation of starch-sugar interactions were the formation of starch-sugar inclusion complexes and the increase in free volume that can lead in less plasticising impact of the starch-sugar solvent [Lim et al., 1992; Levine \& Slade, 1989; Tomasik et al., 1995]. Also sugars significantly influence the thermal properties of starch and the effect depends on the type of sugar, nature of the starch and storage conditions. Starches are widely used in the food industry as a thickening agent or a stabilizer, for providing control of moisture and water mobility, improving overall product quality, reducing cost, and/or facilitating processing [Funami et al., 2005]. Properties of native starch are not optimal in many applications. Chemically-modified starches are the food additives that have a wide range of applications as agents for thickening, texturing, bulking, stabilising and gelling. Application of hydrocolloids in solution stabilisation can replace the application of chemically-modified starches [Korus et al., 2004]. Hydrocolloids are used due to their functional properties like stabilisation of insoluble particle, thickening, and improvement of consistency [Buffo, 2001]. Hydrocolloids, especially guar gum and xanthan gum, are used in the starch-containing foods since those hydrocolloids exhibit many functions to control textural properties 
of foods, to improve moisture retention, and to maintain overall product quality [Funami et al., 2005].

The knowledge of the thermal properties is fundamental for describing and simulating thermal processes, such as heating, cooling, drying, freezing etc. With high water content materials, such as fruits and vegetables, thermal properties are strongly dependent on the fraction of water crystallising as ice or melting during processing. Thermal properties of food such as freezing point, content of freezable water, latent heat of fusion, and enthalpy are factors that can affect freezing temperature manipulation, thermal stability during storage, quality of frozen product during processing, and finally customers acceptation of food products [Roos, 1987; Rahman, 1995; Tocci \& Mascheroni, 1998; Hamdami et al., 2004; Fasina, 2005; Wang et al., 2007].

Fruit cream fillings are used as a component in fruit toppings, doughnuts, pies, cakes and other products. In order to achieve their higher quality some additives can be added.

The aim of this research was to investigate the effect of different sugars (sucrose, fructose and trehalose), modified starches (tapioca and waxy maize) and hydrocolloids (karaya and guar gum) on colour and thermal properties of raspberry cream fillings. Samples were stored for 8 and 16 months at room temperature and quality parameters (colour, anthocyanin content, total phenol content, free radical scavenging) as well as thermal properties were investigated.

\section{MATERIALS AND METHODS}

\section{Plant}

Ripe raspberries of Willamette variety were bought in the summer season of 2011 from domain Orahovica, Croatia and kept at $-20^{\circ} \mathrm{C}$ before use.

\section{Chemicals}

Tapioca modified starch (hydroxy propylo starch; commercially named Textra, moisture content $15.0 \%$, TMS) and waxy maize modified starch (hydroxypropyl di-starch phosphate; commercially named Frigex W, moisture content $15.0 \%$, WMMS) were obtained from National Starch \& Chemical, UK. Karaya gum (KG) and guar gum (GG) were products of Sigma-Aldrich Chemie, Germany. The next ingredients that we used were: sucrose $(\mathrm{S})$, fructose $(\mathrm{F}$, Merck KGaA, Germany) and trehalose (T, Merck KGaA, Germany).

1,1-Diphenyl-2-picrylhydrazyl (DPPH) radical and Folin-Ciocalteu phenol reagent were purchased from Sigma-Aldrich Inc. (St Louis, MO, USA).

\section{Sample preparation}

Raw materials for cream fillings preparation were raspberry puree, sugars, modified starches and hydrocolloids. Cream fillings were prepared by heating of the raw material and the above mentioned-additives at $85^{\circ} \mathrm{C}$ until $35 \%$ of dry matter was achieved $(15 \mathrm{~min})$, filled into the sterile bottles (200 mL) and pasteurised. Fifteen different cream fillings were obtained. Composition of samples is presented in Table 1 and Figure 1. Raspberry cream fillings were stored at $25^{\circ} \mathrm{C}$ in the dark for 16 months and measurements were conducted after preparation, 8 and 16 months.

\section{Determination of the total phenolics content}

The extraction of the phenolic compounds from raspberry cream fillings was carried out with acidified methanol at room temperature for $20 \mathrm{~min}$ and centrifugation at $4000 \mathrm{rpm}$ for $10 \mathrm{~min}$. The obtained extracts were used for determination of total phenols concentration by the Folin-Ciocalteu method [Ough \& Amerine, 1988]. Results of spectrophotometric measurement were interpolated on the gallic acid calibration curve and expressed as mg of gallic acid per $100 \mathrm{~g}$ of the sample. Measurements were done in triplicate.

\section{Measurement of monomeric anthocyanins}

After the isolation of anthocyanins by the extraction method described in the previous section, the extracts were used for the determination of monomeric anthocyanins by $\mathrm{pH}$-differential method [Giusti \& Wrolstad, 2001]. Measurements were done in triplicate. Total monomeric anthocyanins were expressed as cyanidin-3-glucoside. Sample absorbance values were read at 515 and $700 \mathrm{~nm}$ against a blank cell containing distilled water. The absorbance (A) of the diluted sample was then calculated according the following formula:

$$
\mathrm{A}=\left(\mathrm{A}_{515}-\mathrm{A}_{700}\right)_{\mathrm{pH} 1.0}-\left(\mathrm{A}_{515}-\mathrm{A}_{700}\right)_{\mathrm{pH} 4.5}
$$

The monomeric anthocyanin pigment concentration in the original sample was calculated according to the following formula:

$$
\begin{aligned}
& \text { Anthocyanin content }(\mathrm{mg} / \mathrm{kg})= \\
& =(\mathrm{A} \times \mathrm{MW} \times \mathrm{DF} \times 1000) /(\varepsilon \times \mathrm{l})
\end{aligned}
$$

where: MW is molecular weight of cyanidin-3-glucoside (449.2); $\varepsilon$ is the molar absorptivity (26.900); and DF is the dilution factor.

\section{Assay of 2,2-diphenyl-1-picrylhydrazyl radical scavenging activity}

Free radical scavenging activity of the raspberry cream filling samples was measured by 2, 2-diphenyl-1-picrylhydrazyl (DPPH) using the method of Shimada et al. [1992] with slight modifications. Sample extract $(0.2 \mathrm{~mL})$ was diluted with methanol and $1 \mathrm{~mL}$ of a DPPH solution $(0.5 \mathrm{mmol} / \mathrm{L})$ was added. After $30 \mathrm{~min}$, the absorbance was measured at $517 \mathrm{~nm}$. Measurements were done in triplicate. The percentage of the DPPH radical scavenging was calculated from the following equation:

$$
\text { Scavenging activity }(\%)=\left(1-\mathrm{A}_{1} / \mathrm{A}_{0}\right) \times 100
$$

where: $\mathrm{A}_{0}$ was the absorbance of the blank (methanol replacing the extract) and $A_{1}$ was the absorbance in the presence of the sample extract.

\section{Colour measurement}

Colour changes of raspberry cream fillings were monitored with a colorimeter (Minolta CR-300). Measurements were done in triplicate. The chromatic values $\mathrm{L}^{*}, \mathrm{a}^{*}, \mathrm{~b}^{*}$ were used to calculate the total colour difference $\left(\Delta E^{*}\right)$ of the samples. The higher $L^{*}, a^{*}, b^{*}$ values meant higher lightness, red 
TABLE 1. Composition of samples (per $100 \mathrm{~g}$ of sample).

\begin{tabular}{|c|c|c|c|c|c|c|c|c|}
\hline Sample & Raspberry puree & Sucrose & Fructose & Trehalose & TMS & WMMS & $\mathrm{KG}$ & GG \\
\hline Raspberry puree & + & & & & & & & \\
\hline S & + & $+(27 \%)$ & & & & & & \\
\hline $\mathrm{S}+\mathrm{F}$ & + & $+(17 \%)$ & $\begin{array}{c}+ \\
(10 \%)\end{array}$ & & & & & \\
\hline $\mathrm{S}+\mathrm{T}$ & + & $+(25.4 \%)$ & & $\begin{array}{l}+ \\
(1.6 \%)\end{array}$ & & & & \\
\hline $\mathrm{S}+\mathrm{TMS}$ & + & $+(27 \%)$ & & & $\begin{array}{l}+ \\
(1 \%)\end{array}$ & & & \\
\hline S+WMMS & + & $+(27 \%)$ & & & & $\stackrel{+}{+}$ & & \\
\hline $\mathrm{S}+\mathrm{KG}$ & + & $+(27 \%)$ & & & & & $+(0.05 \%)$ & \\
\hline $\mathrm{S}+\mathrm{GG}$ & + & $+(27 \%)$ & & & & & & $+(0.05 \%)$ \\
\hline $\mathrm{S}+\mathrm{F}+\mathrm{TMS}$ & + & $+(17 \%)$ & $\stackrel{+}{+}$ & & $\stackrel{+}{+}$ & & & \\
\hline $\mathrm{S}+\mathrm{F}+\mathrm{WMMS}$ & + & $+(17 \%)$ & $\begin{array}{c}+ \\
(10 \%)\end{array}$ & & & $\begin{array}{c}+ \\
(1 \%)\end{array}$ & & \\
\hline $\mathrm{S}+\mathrm{F}+\mathrm{KG}$ & + & $+(17 \%)$ & $\begin{array}{c}+ \\
(10 \%)\end{array}$ & & & & $+(0.05 \%)$ & \\
\hline $\mathrm{S}+\mathrm{F}+\mathrm{GG}$ & + & $+(17 \%)$ & $\begin{array}{c}+ \\
(10 \%)\end{array}$ & & & & & $+(0.05 \%)$ \\
\hline $\mathrm{S}+\mathrm{T}+\mathrm{TMS}$ & + & $+(25.4 \%)$ & & $\stackrel{+}{+}$ & $\stackrel{+}{+}$ & & & \\
\hline $\mathrm{S}+\mathrm{T}+\mathrm{WMMS}$ & + & $+(25.4 \%)$ & & $\stackrel{+}{(1.6 \%)}$ & & $\stackrel{+}{+}$ & & \\
\hline $\mathrm{S}+\mathrm{T}+\mathrm{KG}$ & + & $+(25.4 \%)$ & & $\stackrel{+}{+}$ & & & $+(0.05 \%)$ & \\
\hline $\mathrm{S}+\mathrm{T}+\mathrm{GG}$ & + & $+(25.4 \%)$ & & $\stackrel{+}{+}$ & & & & $+(0.05 \%)$ \\
\hline
\end{tabular}

S, sucrose; F, fructose; T, trehalose; TMS, tapioca modified starch; WMMS, waxy maize modified starch; KG, karaya gum; GG, guar gum.

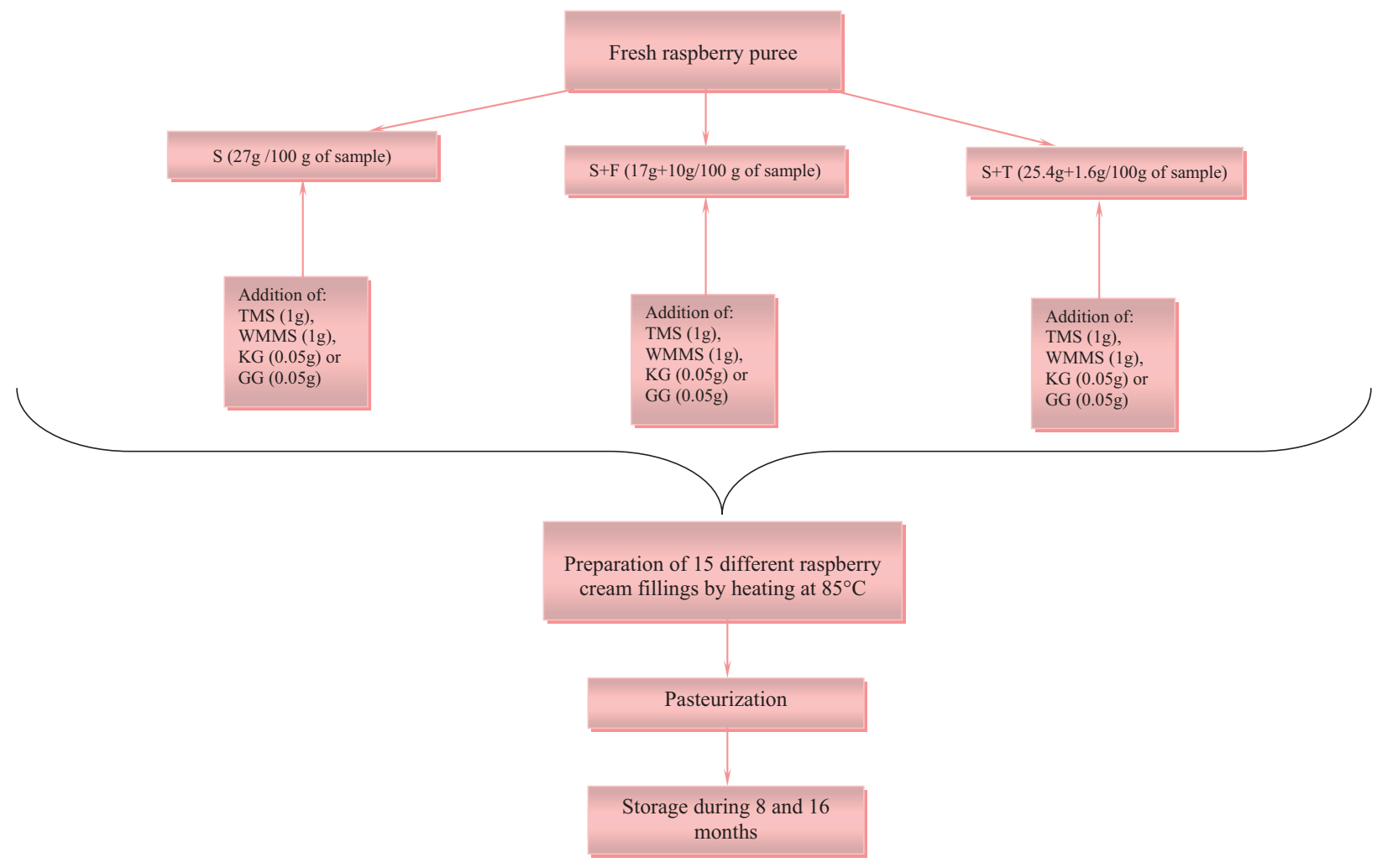

FIGURE 1. Sheme of raspberry cream fillings preparation. 
colour, and yellow colour, respectively. Total colour difference $\left(\Delta \mathrm{E}^{*}\right)$ was calculated according the following formula:

$$
\Delta \mathrm{E}^{*}=\left(\Delta \mathrm{L}^{* 2}+\Delta \mathrm{a}^{* 2}+\Delta \mathrm{b}^{* 2}\right)^{1 / 2}
$$

\section{Determination of thermal properties}

Thermophysical evaluations of the investigated cream fillings were carried out on a computer-controlled differential scanning calorimeter DSC $822^{\circ}$ (Mettler Toledo, Switzerland) equipped with STAR ${ }^{e}$ software.

An empty pan was used as a reference. Raspberry cream fillings were weighed $(20 \mathrm{mg})$ into standard aluminium pans $(40 \mu \mathrm{m})$. The examined cream fillings were placed in a DSC and experiments were conducted at the heating rate of $5^{\circ} \mathrm{C} / \mathrm{min}$ from 25 to $-30^{\circ} \mathrm{C}$. The changes in enthalpy $(\Delta \mathrm{H})$, onset temperature $\left(\mathrm{T}_{0}\right)$, peak temperature $\left(\mathrm{T}_{\mathrm{p}}\right)$ were obtained from the exotherm DSC curve. All measurements were conducted in triplicate.

\section{Determination of moisture content}

Moisture content of raspberry puree and raspberry cream fillings were determined with vacuum oven drying at $70^{\circ} \mathrm{C}$ and $13.3 \mathrm{kPa}$. Three replications were used for determination.

\section{Calculation of unfreezable water fraction}

The unfreezable water content of the sample was determined as described by Duckworth equation [Duckworth, 1971]. The freezable water mass fraction $\left(\omega_{\mathrm{fw}}\right)$ was calculated from the formula:

$$
\omega_{\mathrm{fw}}=\frac{\Delta \mathrm{H}_{m}}{\Delta \mathrm{H}_{w}}
$$

where: $\Delta \mathrm{H}_{m}$ is the enthalpy of ice melting of the sample $(\mathrm{J} / \mathrm{g})$ and $\Delta \mathrm{H}_{w}$ is the latent heat of water melting as a function of temperature, 333.2 J/g [Weast \& Astle, 1981].

The unfreezable water mass fraction $\left(\omega_{\mathrm{ufw}}\right)$ was calculated by the difference between $\omega_{\text {fiw }}$ and the total moisture content (wet basis) of the sample $\left(\omega_{\mathrm{w}}{ }^{\mathrm{w}}\right.$.

$$
\omega_{\mathrm{ufw}}=\omega_{\mathrm{w}}-\omega_{\mathrm{fw}}
$$

The unfreezable water fraction $\left(\dot{\omega}_{\mathrm{g}}\right)$, that based on the total solid content $\left(\omega_{\mathrm{s}}\right)$ was calculated:

$$
\omega_{\mathrm{g}}=\frac{\omega_{u f f_{v}}}{\omega_{s}}
$$

\section{Calculation of thermal conductivity, specific heat capacity and latent heat of fusion}

Thermal conductivity, specific heat capacity and latent heat of fusion were calculated with moisture content of raspberry fruit fillings. Sweat [1974] developed mathematical formula for calculation of the thermal conductivities of fruit and fruit products where the moisture content was higher than $60 \%$.

The mathematical formula connecting the various engineering properties with moisture content of the fruits and their products are as follows:
Thermal conductivity $(\mathrm{K})$ was calculated as:

$$
\mathrm{K}=0.148+0.00493 \mathrm{~W}
$$

where: $\mathrm{K}$ is the thermal conductivity $\left(\mathrm{Js} / \mathrm{m}{ }^{\circ} \mathrm{C}\right)$ and $\mathrm{W}$ is the moisture content (\%).

Specific heat capacity $\left(\mathrm{c}_{\mathrm{p}}\right)$ was calculated according to Dickerson [1969]:

$$
c_{p}=1.675+0.025 \mathrm{~W}
$$

where: $\mathrm{c}_{\mathrm{p}}$ is the specific heat capacity $\left(\mathrm{KJ} / \mathrm{kg}{ }^{\circ} \mathrm{C}\right)$.

Latent heat of fusion $(\lambda)$ was calculated by using methods of Lewis [1987] and Lamb [1976] adopted for latent heat determination:

$$
\lambda=335 \mathrm{~W}
$$

where: $\lambda$ is the latent heat of fusion $(\mathrm{J} / \mathrm{kg})$.

\section{Statistical analysis}

The experimental data were analysed by the analysis of variance (ANOVA) and Fisher's least significant difference (LSD) with significance defined at $\mathrm{P}<0.05$. All statistical analyses were carried out using the software program STATISTICA 8 (StatSoft, Inc.,USA).

\section{RESULTS AND DISCUSSION}

Chemical properties of raspberry cream fillings before and after storage were related to the influence of adding sugars, modified starches, hydrocolloids on colour properties of raspberry cream fillings immediately after preparation and after 8 and 16 months of storage.

Fresh raspberry puree had $420 \mathrm{mg} \mathrm{GAE} / 100 \mathrm{~g}$ of total phenolic compounds and $99.25 \mathrm{mg} / 100 \mathrm{~g}$ of anthocyanins. During pasteurisation, degradation of total phenols and anthocyanins occurred. All samples with the addition of additives were compared with pasteurised raspberry puree (control sample).

It can be seen that the total phenolic content of all raspberry cream filling samples followed the trend observed with anthocyanin content. After the preparation, in cream fillings with only sugars addition the highest total phenolic content was in the sample with ST (318 mg GAE/100 g); in combination of sugars and modified starches or hydrocolloids the highest total phenol content was in the sample prepared with mixture of ST and WMMS (405 mg GAE/100 g) or GG (411 mg GAE/100 g) (Table 2). During storage within 8 and 16 months, the total phenolic content decreased in all samples but the lowest decrease was noticed in the sample with the addition of sucrose and trehalose in combination with GG (Table 2).

The anthocyanin content was measured in raspberry cream fillings with the addition of sugars, modified starches and hydrocolloids. The results for anthocyanin content of raspberry cream fillings are shown in Table 3. Anthocyanin content in pasteurised raspberry puree (control sample) was $38.21 \mathrm{mg} / 100 \mathrm{~g}$. After the preparation, in samples pre- 
TABLE 2. Total phenolic content (mg GAE/100 g) of raspberry cream fillings after preparation and after 8 and 16 months of storage at room temperature.

\begin{tabular}{|c|c|c|c|}
\hline \multirow[b]{2}{*}{ Samples } & \multicolumn{3}{|c|}{ Total phenolic content (mg GAE/100 g) } \\
\hline & $\begin{array}{c}\text { After } \\
\text { preparation }\end{array}$ & $\begin{array}{c}\text { After } \\
8 \text { months } \\
\text { of storage }\end{array}$ & $\begin{array}{c}\text { After } \\
16 \text { months } \\
\text { of storage }\end{array}$ \\
\hline $\begin{array}{l}\text { Fresh raspberry } \\
\text { puree }\end{array}$ & $420 \pm 2.14^{\mathrm{d}}$ & & \\
\hline $\begin{array}{l}\text { Pasteurized } \\
\text { raspberry puree }\end{array}$ & $154 \pm 1.08^{a}$ & & \\
\hline S & $271 \pm 0.17^{b}$ & $203 \pm 0.08^{a}$ & $148 \pm 0.61^{\mathrm{a}}$ \\
\hline $\mathrm{S}+\mathrm{F}$ & $271 \pm 0.44^{b}$ & $207 \pm 0.52^{b}$ & $178 \pm 0.21^{b}$ \\
\hline $\mathrm{S}+\mathrm{T}$ & $318 \pm 0.29^{c}$ & $289 \pm 0.12^{c}$ & $204 \pm 0.14^{c}$ \\
\hline $\mathrm{S}+\mathrm{TMS}$ & $281 \pm 0.21^{\mathrm{a}}$ & $217 \pm 0.58^{a}$ & $192 \pm 0.47^{b}$ \\
\hline $\mathrm{S}+\mathrm{WMMS}$ & $301 \pm 0.02^{b}$ & $231 \pm 0.29^{b}$ & $183 \pm 0.17^{\mathrm{a}}$ \\
\hline $\mathrm{S}+\mathrm{F}+\mathrm{TMS}$ & $324 \pm 0.19^{c}$ & $304 \pm 0.03^{c}$ & $210 \pm 0.23^{c}$ \\
\hline $\mathrm{S}+\mathrm{F}+\mathrm{WMMS}$ & $331 \pm 0.07^{\mathrm{d}}$ & $312 \pm 0.01^{\mathrm{d}}$ & $257 \pm 0.29^{d}$ \\
\hline $\mathrm{S}+\mathrm{T}+\mathrm{TMS}$ & $349 \pm 0.21^{\mathrm{e}}$ & $329 \pm 0.26^{\mathrm{f}}$ & $264 \pm 0.11^{\mathrm{e}}$ \\
\hline $\mathrm{S}+\mathrm{T}+\mathrm{WMMS}$ & $405 \pm 0.48^{\mathrm{f}}$ & $326 \pm 0.19^{\mathrm{e}}$ & $286 \pm 0.09^{f}$ \\
\hline $\mathrm{S}+\mathrm{KG}$ & $313 \pm 0.06^{\mathrm{a}}$ & $261 \pm 0.44^{\mathrm{a}}$ & $202 \pm 0.17^{b}$ \\
\hline $\mathrm{S}+\mathrm{GG}$ & $315 \pm 0.82^{b}$ & $268 \pm 0.17^{b}$ & $201 \pm 0.11^{\mathrm{a}}$ \\
\hline $\mathrm{S}+\mathrm{F}+\mathrm{KG}$ & $339 \pm 0.24^{c}$ & $293 \pm 0.17^{c}$ & $209 \pm 0.75^{c}$ \\
\hline $\mathrm{S}+\mathrm{F}+\mathrm{GG}$ & $349 \pm 0.03^{\mathrm{d}}$ & $306 \pm 0.06^{\mathrm{d}}$ & $229 \pm 0.14^{\mathrm{d}}$ \\
\hline $\mathrm{S}+\mathrm{T}+\mathrm{KG}$ & $373 \pm 0.47^{e}$ & $349 \pm 0.05^{\mathrm{e}}$ & $314 \pm 0.37^{\mathrm{e}}$ \\
\hline $\mathrm{S}+\mathrm{T}+\mathrm{GG}$ & $411 \pm 0.24^{\mathrm{f}}$ & $373 \pm 0.18^{\mathrm{f}}$ & $356 \pm 0.11^{\mathrm{f}}$ \\
\hline
\end{tabular}

Values are means \pm SD of triplicate. Values in the same column with different superscripts (a-e) are significantly different $(\mathrm{P}<0.05)$.

pared only with the addition of sugars, the highest content of anthocyanins was found in the raspberry cream filling with the addition of ST $(66.49 \mathrm{mg} / 100 \mathrm{~g})$. It is known that a high concentration of sugar in fruit preserves stabilises anthocyanins [Wrolstad et al., 1990]. This impact could be explained by the fact that sugar addition reduces water activity $\left(a_{\mathrm{w}}\right)$. The influence of modified starches addition was also monitored. The raspberry cream filling sample prepared with the mixture of ST and with WMMS had the highest anthocyanin content $(85.41 \mathrm{mg} / 100 \mathrm{~g})$. Addition of hydrocolloids also had a positive effect on anthocyanin content. The measured values of anthocyanin content of raspberry cream fillings with the addition of sugars (S, SF, ST) and hydrocolloids (KG, GG) showed that ST in combination with GG had the higher impact on anthocyanin content retention $(98.73 \mathrm{mg} / 100 \mathrm{~g})$. After 8 months of storage at room temperature (Table 3), the loss of anthocyanin content occurred, but the influence of trehalose was still noticeable. In the samples prepared only with sugars addition, the highest content of anthocyanins was found in cream filling with ST $(8.56 \mathrm{mg} / 100 \mathrm{~g})$. The samples made with sugars and modified starches showed that the combination of ST and WMMS gave the highest anthocyanin content $(15.13 \mathrm{mg} / 100 \mathrm{~g})$. When analysing hydrocolloids
TABLE 3. Anthocyanin content $(\mathrm{mg} / 100 \mathrm{~g}$ ) of raspberry cream fillings after preparation and after 8 and 16 months of storage at room temperature.

\begin{tabular}{|c|c|c|c|}
\hline \multirow[b]{2}{*}{ Samples } & \multicolumn{3}{|c|}{$\mathrm{AC}(\mathrm{mg} / 100 \mathrm{~g})$} \\
\hline & $\begin{array}{c}\text { After } \\
\text { preparation }\end{array}$ & $\begin{array}{c}\text { After } \\
8 \text { months } \\
\text { of storage }\end{array}$ & $\begin{array}{c}\text { After } \\
16 \text { months } \\
\text { of storage }\end{array}$ \\
\hline $\begin{array}{l}\text { Fresh raspberry } \\
\text { puree }\end{array}$ & $99.25 \pm 1.67^{\mathrm{e}}$ & & \\
\hline $\begin{array}{l}\text { Pasteurized } \\
\text { raspberry puree }\end{array}$ & $38.21 \pm 1.35^{\mathrm{a}}$ & & \\
\hline S & $45.65 \pm 1.47^{b}$ & $4.77 \pm 1.05^{\mathrm{a}}$ & $2.24 \pm 0.92^{\mathrm{a}}$ \\
\hline $\mathrm{S}+\mathrm{F}$ & $51.25 \pm 1.29^{c}$ & $6.25 \pm 1.73^{\mathrm{a}, \mathrm{b}}$ & $2.75 \pm 0.87^{\mathrm{a}}$ \\
\hline $\mathrm{S}+\mathrm{T}$ & $66.49 \pm 1.61^{\mathrm{d}}$ & $8.56 \pm 1.47^{\mathrm{b}}$ & $4.25 \pm 1.15^{\mathrm{a}}$ \\
\hline $\mathrm{S}+\mathrm{TMS}$ & $52.75 \pm 0.86^{\mathrm{a}}$ & $6.44 \pm 1.41^{\mathrm{a}}$ & $2.45 \pm 1.26^{\mathrm{a}}$ \\
\hline $\mathrm{S}+\mathrm{WMMS}$ & $60.89 \pm 1.71^{b}$ & $6.82 \pm 0.83^{a}$ & $3.31 \pm 0.51^{\mathrm{a}}$ \\
\hline $\mathrm{S}+\mathrm{F}+\mathrm{TMS}$ & $73.19 \pm 1.21^{\mathrm{c}}$ & $9.14 \pm 1.07^{\mathrm{b}}$ & $4.59 \pm 0.32^{\mathrm{b}}$ \\
\hline $\mathrm{S}+\mathrm{F}+\mathrm{WMMS}$ & $74.30 \pm 1.75^{c}$ & $14.87 \pm 1.86^{\mathrm{c}}$ & $5.17 \pm 1.83^{\mathrm{b}}$ \\
\hline $\mathrm{S}+\mathrm{T}+\mathrm{TMS}$ & $81.01 \pm 1.29^{\mathrm{d}}$ & $15.09 \pm 0.63^{c}$ & $5.48 \pm 0.87^{\mathrm{b}}$ \\
\hline $\mathrm{S}+\mathrm{T}+\mathrm{WMMS}$ & $85.41 \pm 1.69^{\mathrm{e}}$ & $15.13 \pm 0.95^{c}$ & $8.02 \pm 1.01^{\circ}$ \\
\hline $\mathrm{S}+\mathrm{KG}$ & $61.63 \pm 0.93^{\mathrm{a}}$ & $7.02 \pm 1.63^{\mathrm{a}}$ & $3.43 \pm 1.18^{\mathrm{a}}$ \\
\hline $\mathrm{S}+\mathrm{GG}$ & $65.76 \pm 1.41^{b}$ & $7.53 \pm 1.95^{\mathrm{a}}$ & $3.92 \pm 1.36^{\mathrm{a}}$ \\
\hline $\mathrm{S}+\mathrm{F}+\mathrm{KG}$ & $76.87 \pm 1.21^{\mathrm{c}}$ & $8.91 \pm 0.86^{\mathrm{a}}$ & $4.28 \pm 1.18^{\mathrm{a}}$ \\
\hline $\mathrm{S}+\mathrm{F}+\mathrm{GG}$ & $77.55 \pm 1.71^{\mathrm{c}}$ & $12.58 \pm 1.21^{\mathrm{b}}$ & $5.11 \pm 0.89^{\mathrm{a}}$ \\
\hline $\mathrm{S}+\mathrm{T}+\mathrm{KG}$ & $95.61 \pm 1.78^{d}$ & $15.61 \pm 0.53^{\mathrm{c}}$ & $8.76 \pm 1.27^{\mathrm{b}}$ \\
\hline $\mathrm{S}+\mathrm{T}+\mathrm{GG}$ & $98.73 \pm 0.99^{\mathrm{e}}$ & $25.55 \pm 1.12^{\mathrm{d}}$ & $14.93 \pm 0.53^{\circ}$ \\
\hline
\end{tabular}

Values are means \pm SD of triplicate. Values in the same column with different superscripts (a-e) are significantly different $(\mathrm{P}<0.05)$.

*Total anthocyanin content was expressed as mg of cyanidin-3-glucoside per $100 \mathrm{~g}$ of initial product, determined by $\mathrm{pH}$-differential method.

and sugars addition into cream fillings, the highest content of anthocyanins was also found in the sample ST with GG $(25.55 \mathrm{mg} / 100 \mathrm{~g})$. After 16 months of storage, all samples with sucrose and trehalose improved anthocyanin stability to a higher or lesser extent. The highest anthocyanin content in cream fillings with sugars combination was found for ST $(4.25 \mathrm{mg} / 100 \mathrm{~g})$, in cream fillings with sugars and modified starches combinations - for ST + WMMS $(8.02 \mathrm{mg} / 100 \mathrm{~g})$, whereas in these with sugars and hydrocolloids - for ST + GG (14.93 mg/100 g).

An intensely coloured solution can be preserved by the prevention of water binding to the flavylium ring. Removal of water and displacement of hydration/dehydration equilibrium towards to the coloured species can be the possible mechanism of retention of anthocyanin colour (i.e. reduction of hydration reaction extent) [Brouillard, 1983]. It is well known that sugar causes decrease in water activity and sugar molecules are effective at binding water [Coultate, 1989]; so in this way sugars could protect anthocyanins from water attack, thereby increasing their stability. Also, for thermal degradation of anthocyanins two mechanisms were suggested. One includes hydrolysis of the 3-glycoside linkage to 
TABLE 4. Free radical scavenging activity (\%) of raspberry cream fillings after preparation and after 8 and 16 months of storage at room temperature.

\begin{tabular}{l|c|c|c}
\hline \multirow{2}{*}{ Samples } & \multicolumn{3}{|c}{ Free radical scavenging activity $\%)$} \\
\cline { 2 - 4 } & $\begin{array}{c}\text { After } \\
\text { preparation }\end{array}$ & $\begin{array}{c}\text { After } \\
8 \text { months } \\
\text { of storage }\end{array}$ & $\begin{array}{c}\text { After } \\
16 \text { months } \\
\text { of storage }\end{array}$ \\
\hline $\begin{array}{l}\text { Fresh raspberry } \\
\text { puree }\end{array}$ & $96.66 \pm 1.67^{\mathrm{d}}$ & & \\
$\begin{array}{l}\text { Pasteurized } \\
\text { raspberry puree }\end{array}$ & $87.76 \pm 0.91^{\mathrm{a}}$ & & \\
S & $87.87 \pm 0.73^{\mathrm{a}}$ & $19.49 \pm 0.15^{\mathrm{b}}$ & $11.38 \pm 1.19^{\mathrm{a}, \mathrm{b}}$ \\
S+F & $88.64 \pm 0.03^{\mathrm{b}}$ & $14.53 \pm 0.33^{\mathrm{a}}$ & $11.47 \pm 0.43^{\mathrm{a}}$ \\
S+T & $89.58 \pm 0.29^{\mathrm{c}}$ & $19.97 \pm 0.22^{\mathrm{b}}$ & $12.88 \pm 0.79^{\mathrm{b}}$ \\
\hline S+TMS & $88.11 \pm 1.02^{\mathrm{a}}$ & $19.49 \pm 0.25^{\mathrm{a}}$ & $11.99 \pm 0.83^{\mathrm{a}}$ \\
S+WMMS & $88.85 \pm 0.24^{\mathrm{b}}$ & $19.54 \pm 0.36^{\mathrm{a}}$ & $12.52 \pm 0.58^{\mathrm{a}, \mathrm{b}}$ \\
S+F+TMS & $89.42 \pm 0.95^{\mathrm{c}}$ & $20.74 \pm 0.41^{\mathrm{b}}$ & $14.01 \pm 0.97^{\mathrm{b}, \mathrm{c}}$ \\
S+F+WMMS & $90.39 \pm 1.27^{\mathrm{d}}$ & $20.69 \pm 0.57^{\mathrm{b}}$ & $15.69 \pm 1.03^{\mathrm{c}}$ \\
S+T+TMS & $91.04 \pm 0.52^{\mathrm{e}}$ & $20.74 \pm 0.38^{\mathrm{b}}$ & $15.91 \pm 1.51^{\mathrm{c}}$ \\
S+T+WMMS & $92.12 \pm 0.72^{\mathrm{f}}$ & $20.83 \pm 0.23^{\mathrm{b}}$ & $16.39 \pm 1.71^{\mathrm{c}}$ \\
\hline S+KG & $89.26 \pm 0.87^{\mathrm{a}}$ & $19.69 \pm 0.51^{\mathrm{b}}$ & $12.86 \pm 0.22^{\mathrm{a}}$ \\
S+GG & $89.17 \pm 0.67^{\mathrm{a}}$ & $18.49 \pm 0.39^{\mathrm{a}}$ & $12.48 \pm 1.03^{\mathrm{a}}$ \\
S+F+KG & $90.94 \pm 0.72^{\mathrm{b}}$ & $20.49 \pm 0.52^{\mathrm{b}, \mathrm{c}}$ & $13.09 \pm 0.54^{\mathrm{a}}$ \\
S+F+GG & $90.96 \pm 0.29^{\mathrm{c}}$ & $20.49 \pm 0.46^{\mathrm{b}, \mathrm{c}}$ & $15.05 \pm 0.88^{\mathrm{b}}$ \\
\hline S+T+KG & $91.51 \pm 0.72^{\mathrm{d}}$ & $20.97 \pm 0.44^{\mathrm{c}}$ & $16.22 \pm 1.27^{\mathrm{b}}$ \\
\hline & $92.20 \pm 1.12^{\mathrm{e}}$ & $21.45 \pm 0.64^{\mathrm{c}}$ & $19.31 \pm 0.66^{\mathrm{c}}$ \\
\hline
\end{tabular}

Values are means \pm SD of triplicate. Values in the same column with different superscripts $(\mathrm{a}-\mathrm{e})$ are significantly different $(\mathrm{P}<0.05)$.

form the more labile aglycon; and other hydrolytic opening of the pyrylium ring to form a substituted chalcone, which then degrades to a brown insoluble compound of a polyphenolic nature [Simpson, 1985]. Probably, trehalose during raspberry cream filling preparation suppresses one of these two mechanisms responsible for thermal degradation of anthocyanins, to a higher extent than other two sugars do. Also, the ability of sugar molecules to bind protectively onto the surface of molecular structures has also been ascribed to their ability to form hydrogen bonds, the so-called "water replacement hypothesis". In comparison to other disaccharides, trehalose has no direct internal bonds. All of four internal bonds in trehalose structure are indirectly connected to the two molecules of water and form part of the native dihydrate structure. This structure of trehalose causes unusual flexibility around the disaccharide bond allowing its fitting more closely with the irregular surface of macromolecules in comparison to disaccharides with a more rigid structure due to directly hydrogen bonded rings [Colaco \& Roser, 1995]. Also, trehalose is stable in acidic conditions and at high temperatures [Colaco \& Roser, 1995].

Change of free radical scavenging activity followed the trend of total phenol and anthocyanin content. The high- est percentage of free radical scavenging activity had the samples with ST: after preparation in sugar combinations ST $(89.58 \%)$; in combination with sugars and modified starches ST + WMMS $(92.12 \%)$ and the samples with sugars and hydrocolloids ST + GG (92.20\%). The smallest percentage of free radical scavenging activity had the sample with only sucrose addition (S 87.87\%) (Table 4). During storage within 8 and 16 months, free radical scavenging activity decreased in all samples but the highest percentage of free radical scavenging activity was noticed in the sample with the addition of ST in combination with GG $(21.45 \%$ and $19.31 \%$, respectively).

After the preparation of samples, there were no significant colour differences between samples prepared only with sugars addition. The samples with ST addition in combination with hydrocolloids $(\mathrm{GG}, \mathrm{KG})$ or modified starches (TMS, WMMS) had higher $L^{*}, a^{*}$ and $b^{*}$ values than the samples with the addition of sucrose and fructose or only with sucrose in the same combination of hydrocolloids or modified starches (Table 5). After 8 months of storage, the lowest colour change expressed as total colour difference (DE) was found in the samples with the addition of SF and KG (3.72) and the highest colour difference was determined in the sample with the addition of $\mathrm{S}$ and $\mathrm{KG}$ (5.87) (Table 5). After 16 months of storage, the highest colour difference was in the sample with the addition of ST and GG (8.78), and the lowest colour difference was found in the sample with the addition of S and TMS (5.39) (Table 5).

Thermal properties of raspberry cream fillings before and after storage involved the influence of adding sugars, modified starches, and hydrocolloids on thermal properties of raspberry cream fillings immediately after preparation and after 8 and 16 months of storage (Tables 6-7). Temperature (onset, $\mathrm{T}_{0}$; peak, $\mathrm{T}_{\mathrm{p}}$ ), freezing enthalpy, and moisture content of raspberry cream fillings were determined and those parameters were used for calculation of selected thermal properties specific heat capacity, thermal conductivity and latent heat of fusion.

There were no significant differences in freezing temperature of samples SF $\left(-19.28{ }^{\circ} \mathrm{C}\right)$ and ST $\left(-20.19{ }^{\circ} \mathrm{C}\right)$ while sample $\mathrm{S}$ had a higher value $\left(-18.20^{\circ} \mathrm{C}\right)$ (Table 6). This could be explained with the fact that a change in sugar composition can alter freezing point. From data in Table 6 it was seen that further temperature depression of freezing during 8 months of storage occurred in all raspberry cream fillings with sugars addition. After 8 months of storage, the lowest enthalpy of freezing was determined for the cream filling $\mathrm{SF}(103.48 \mathrm{~J} / \mathrm{s})$ and the highest one for the cream filling S (107.94 J/s). Storage for 16 months resulted in a slight increase of freezing temperature in cream fillings with sugar addition.

Modified starches, as hydrophilic substances, bounded one part of water and hampered the transfer of mass [Wang et al., 2012]. The measured values of freezing thermal properties of raspberry cream fillings with the addition of sugars and modified starches showed that WMMS had a greater impact on freezing point temperature depression than TMS (Table 6). Data in Table 6 showed that storage within 8 months affected freezing temperature as well as enthalpies in all cream fillings with the addition of modified starches. 
TABLE 5. Colour parameters and total difference of raspberry cream fillings after preparation and storage for 8 and 16 months.

\begin{tabular}{|c|c|c|c|c|c|c|c|c|c|}
\hline \multirow{2}{*}{ Samples } & $\mathrm{L}^{*}$ & $a^{*}$ & $b^{*}$ & $L^{*}$ & $a^{*}$ & $b^{*}$ & $L^{*}$ & $a^{*}$ & $b^{*}$ \\
\hline & \multicolumn{3}{|c|}{ After preparation } & \multicolumn{3}{|c|}{ After 8 months of storage } & \multicolumn{3}{|c|}{ After 16 months of storage } \\
\hline $\begin{array}{l}\text { Fresh raspberry } \\
\text { puree }\end{array}$ & $31.23 \pm 0.04^{d}$ & $19.39 \pm 0.04^{d}$ & $6.69 \pm 0.07^{d}$ & & & & & & \\
\hline $\begin{array}{l}\text { Pasteurized } \\
\text { raspberry puree }\end{array}$ & $26.6 \pm 0.03^{\mathrm{a}}$ & $9.78 \pm 0.06^{\mathrm{a}}$ & $2.57 \pm 0.06^{\mathrm{a}}$ & & & & & & \\
\hline S & $27.98 \pm 0.05^{\mathrm{b}}$ & $10.59 \pm 0.07^{\mathrm{b}}$ & $3.07 \pm 0.01^{\mathrm{b}}$ & $27.89 \pm 0.08^{\mathrm{a}}$ & $6.46 \pm 0.02^{\mathrm{a}}$ & $2.09 \pm 0.08^{\mathrm{a}}$ & $28.19 \pm 0.04^{\mathrm{a}}$ & $5.15 \pm 0.11^{\mathrm{a}}$ & $1.51 \pm 0.08^{\mathrm{a}}$ \\
\hline $\mathrm{S}+\mathrm{F}$ & $28.08 \pm 0.05^{\mathrm{b}}$ & $10.72 \pm 0.17^{\mathrm{b}}$ & $3.04 \pm 0.03^{\mathrm{b}}$ & $28.24 \pm 0.08^{b}$ & $6.61 \pm 0.07^{\mathrm{b}}$ & $2.31 \pm 0.08^{b}$ & $28.16 \pm 0.11^{\mathrm{a}}$ & $5.22 \pm 0.06^{\mathrm{a}}$ & $1.74 \pm 0.09^{\mathrm{b}}$ \\
\hline $\mathrm{S}+\mathrm{T}$ & $28.44 \pm 0.04^{c}$ & $11.73 \pm 0.12^{\mathrm{c}}$ & $3.52 \pm 0.03^{\mathrm{c}}$ & $28.17 \pm 0.07^{\mathrm{b}}$ & $7.95 \pm 0.13^{c}$ & $2.35 \pm 0.11^{\mathrm{b}}$ & $28.44 \pm 0.08^{\mathrm{b}}$ & $5.64 \pm 0.05^{\mathrm{b}}$ & $1.95 \pm 0.09^{\mathrm{c}}$ \\
\hline S+TMS & $27.27 \pm 0.06^{\mathrm{a}}$ & $10.13 \pm 0.03^{\mathrm{a}}$ & $2.86 \pm 0.05^{\mathrm{a}}$ & $28.04 \pm 0.09^{\mathrm{a}}$ & $5.41 \pm 0.09^{\mathrm{a}}$ & $1.84 \pm 0.10^{\mathrm{a}}$ & $28.28 \pm 0.04^{\mathrm{b}}$ & $4.89 \pm 0.07^{\mathrm{a}}$ & $1.66 \pm 0.09^{\mathrm{b}}$ \\
\hline S+WMMS & $27.86 \pm 0.04^{b}$ & $10.63 \pm 0.13^{\mathrm{b}}$ & $2.97 \pm 0.06^{\mathrm{a}, \mathrm{b}}$ & $28.58 \pm 0.08^{\mathrm{c}}$ & $6.44 \pm 0.06^{\mathrm{b}}$ & $2.34 \pm 0.06^{\mathrm{b}}$ & $28.49 \pm 0.09^{c}$ & $5.13 \pm 0.09^{\mathrm{b}}$ & $1.77 \pm 0.07^{\mathrm{b}}$ \\
\hline $\mathrm{S}+\mathrm{F}+\mathrm{TMS}$ & $28.07 \pm 0.05^{\mathrm{c}}$ & $10.86 \pm 0.05^{\mathrm{b}}$ & $3.03 \pm 0.09^{\mathrm{b}, \mathrm{c}}$ & $28.49 \pm 0.04^{c}$ & $6.75 \pm 0.06^{\mathrm{c}}$ & $2.37 \pm 0.11^{\mathrm{b}}$ & $28.42 \pm 0.03^{\mathrm{c}}$ & $5.34 \pm 0.08^{\mathrm{c}}$ & $1.91 \pm 0.05^{\mathrm{c}}$ \\
\hline $\mathrm{S}+\mathrm{F}+\mathrm{WMMS}$ & $28.21 \pm 0.06^{\mathrm{d}}$ & $11.37 \pm 0.07^{\mathrm{c}}$ & $3.19 \pm 0.08^{c}$ & $28.24 \pm 0.09^{\mathrm{b}}$ & $7.63 \pm 0.05^{\mathrm{d}}$ & $2.29 \pm 0.12^{\mathrm{b}}$ & $27.91 \pm 0.07^{\mathrm{a}}$ & $5.59 \pm 0.06^{\mathrm{d}}$ & $1.38 \pm 0.06^{\mathrm{a}}$ \\
\hline $\mathrm{S}+\mathrm{T}+\mathrm{TMS}$ & $28.44 \pm 0.06^{\mathrm{c}}$ & $11.92 \pm 0.06^{\mathrm{d}}$ & $3.53 \pm 0.03^{\mathrm{d}}$ & $28.96 \pm 0.03^{d}$ & $8.03 \pm 0.11^{\mathrm{e}}$ & $2.78 \pm 0.06^{\mathrm{c}}$ & $28.87 \pm 0.09^{\mathrm{d}}$ & $6,22 \pm 0.10^{e}$ & $1.84 \pm 0.11^{\mathrm{b}, c}$ \\
\hline $\mathrm{S}+\mathrm{T}+\mathrm{WMMS}$ & $28.65 \pm 0.05^{\mathrm{f}}$ & $12.97 \pm 0.06^{\mathrm{e}}$ & $3.90 \pm 0.04^{\mathrm{e}}$ & $28.29 \pm 0.05^{\mathrm{b}}$ & $8.80 \pm 0.07^{\mathrm{f}}$ & $3.19 \pm 0.04^{\mathrm{d}}$ & $28.97 \pm 0.11^{\mathrm{d}}$ & $6.73 \pm 0.06^{\mathrm{f}}$ & $2.43 \pm 0.03^{\mathrm{d}}$ \\
\hline $\mathrm{S}+\mathrm{KG}$ & $27.88 \pm 0.05^{\mathrm{a}}$ & $10.44 \pm 0.13^{\mathrm{a}}$ & $2.98 \pm 0.09^{\mathrm{a}}$ & $27.83 \pm 0.13^{\mathrm{b}}$ & $4.77 \pm 0.08^{\mathrm{a}}$ & $1.44 \pm 0.08^{\mathrm{a}}$ & $28.21 \pm 0.08^{\mathrm{a}}$ & $4.87 \pm 0.15^{\mathrm{a}}$ & $1.69 \pm 0.09^{\mathrm{a}}$ \\
\hline $\mathrm{S}+\mathrm{GG}$ & $27.97 \pm 0.07^{\mathrm{a}}$ & $10.66 \pm 0.05^{\mathrm{b}}$ & $3.02 \pm 0.09^{\mathrm{a}}$ & $27.31 \pm 0.04^{\mathrm{a}}$ & $5.91 \pm 0.05^{\mathrm{b}}$ & $1.50 \pm 0.04^{\mathrm{a}}$ & $28.43 \pm 0.07^{b}$ & $5.07 \pm 0.07^{\mathrm{a}}$ & $1.91 \pm 0.04^{\mathrm{b}}$ \\
\hline $\mathrm{S}+\mathrm{F}+\mathrm{KG}$ & $28.27 \pm 0.04^{b}$ & $11.23 \pm 0.11^{\mathrm{c}}$ & $3.27 \pm 0.05^{\mathrm{b}}$ & $28.85 \pm 0.08^{d}$ & $7.59 \pm 0.08^{\mathrm{c}}$ & $2.76 \pm 0.11^{\mathrm{c}}$ & $28.26 \pm 0.08^{\mathrm{a}}$ & $5.39 \pm 0.04^{\mathrm{b}}$ & $1.74 \pm 0.04^{a}$ \\
\hline $\mathrm{S}+\mathrm{F}+\mathrm{GG}$ & $28.34 \pm 0.09^{\mathrm{b}}$ & $11.69 \pm 0.07^{\mathrm{d}}$ & $3.37 \pm 0.05^{\mathrm{b}}$ & $28.89 \pm 0.18^{\mathrm{d}}$ & $7.62 \pm 0.18^{c}$ & $2.49 \pm 0.11^{\mathrm{b}}$ & $28.63 \pm 0.13^{b, c}$ & $5.58 \pm 0.12^{\mathrm{c}}$ & $1.85 \pm 0.13^{\mathrm{a}, \mathrm{b}}$ \\
\hline $\mathrm{S}+\mathrm{T}+\mathrm{KG}$ & $28.68 \pm 0.07^{\circ}$ & $12.47 \pm 0.08^{\mathrm{e}}$ & $3.78 \pm 0.12^{\mathrm{c}}$ & $28.53 \pm 0.05^{c}$ & $8.32 \pm 0.07^{\mathrm{d}}$ & $2.57 \pm 0.03^{\mathrm{b}}$ & $28.72 \pm 0.06^{\mathrm{c}}$ & $6.49 \pm 0.03^{\mathrm{d}}$ & $2.26 \pm 0.09^{c}$ \\
\hline $\mathrm{S}+\mathrm{T}+\mathrm{GG}$ & $29.53 \pm 0.03^{\mathrm{d}}$ & $15.09 \pm 0.07^{\mathrm{f}}$ & $4.93 \pm 0.06^{\mathrm{d}}$ & $29.44 \pm 0.06^{\mathrm{e}}$ & $10.38 \pm 0.11^{\mathrm{e}}$ & $3.42 \pm 0.08^{\mathrm{d}}$ & $28.95 \pm 0.07^{\mathrm{d}}$ & $6.74 \pm 0.11^{\mathrm{e}}$ & $2.29 \pm 0.09^{c}$ \\
\hline
\end{tabular}

Values are means \pm SD of triplicate. Values in the same column with different superscripts (a-f) are significantly different $(\mathrm{P}<0.05)$.

The lowest enthalpy of freezing was found in the cream filling $\mathrm{SF}+\mathrm{WMMS}(93.75 \mathrm{~J} / \mathrm{s})$ and the highest one in the cream filling ST+TMS $(110.55 \mathrm{~J} / \mathrm{s})$.

As it was the case in the samples without hydrocolloid addition, the composition of sugar caused different tendency in freezing temperature, probably due to interactions of hydrocolloids with sugars. The measured values of freezing temperatures of raspberry cream fillings with the addition of sugars and hydrocolloids showed that $\mathrm{KG}$ had a greater impact on freezing point temperature depression than GG (Table 6). From data in Table 6 it was seen that further temperature depression of freezing during 8 months of storage occurred in all of the raspberry cream fillings with hydrocolloids addition. There was no significant difference in freezing temperatures after 16 months of storage in all cream fillings with the addition of hydrocolloids except $\mathrm{ST}+\mathrm{GG}\left(-22.06^{\circ} \mathrm{C}\right)$ where temperature decrease was observed (compared with the values measured after 8 months of storage).

The moisture content of fruit and vegetables is very important in determination of the shelf life of unprocessed and processed fruit and vegetables and affects their physicochemical properties. Results in Table 7 showed that the moisture content of all of investigated raspberry cream fillings was higher than $60 \%$, which was suitable for spoilage organisms, but spoilage was avoided with pasteurisation. The other ways, which these cream fillings can be preserved, include refrigeration or freezing, which require transfer of heat to achieve them. The addition of different mixtures of sugars and modified starches or sugars and hydrocolloids in raspberry puree decreased the initial moisture content of the basic puree $(92.16 \%)$. The formation of ice in high moisture content samples cause an increase of concentration of dissolved solids and a decrease in freezing temperature of the remaining water. Consequently, the formation of an amorphous freeze-concentrated phase occurs that contains unfrozen water within the ice phase [Roos et al., 1996].

By the definition, specific heat capacity is the quantity of heat gained or lost by a unit mass of fruits and their products, which is needed to make unit change in temperature. The specific heat capacity for basic raspberry puree without additives was $3.98 \mathrm{~kJ} / \mathrm{kg}^{\circ} \mathrm{C}$; for cream filling with the addition of sugars ranged from 3.25 to $3.27 \mathrm{~kJ} / \mathrm{kg}{ }^{\circ} \mathrm{C}$; for cream filling with sugars and modified starches addition from 3.20 to $3.24 \mathrm{~kJ} / \mathrm{kg}{ }^{\circ} \mathrm{C}$; for cream filling with sugars and hydrocolloids addition from 3.20 to $3.26 \mathrm{~kJ} / \mathrm{kg}{ }^{\circ} \mathrm{C}$ (Table 7). The specific heat capacity of the basic raspberry puree without additives was higher than that of the cream fillings with sugars, modified starches and hydrocolloids. Lots of energy would be required to heat or cool raspberry cream fillings because they had large moisture content and they retained their temperature for long time. Lamb [1976] reported that water retains its temperature for long-time because of its high specific heat capacity value. 
TABLE 6. Freezing points $\left(\mathrm{t}_{0}\right.$ and $\left.\mathrm{t}_{\mathrm{p}}\right)$ and enthalpy of freezing of raspberry cream fillings after preparation and storage of 8 and 16 months.

\begin{tabular}{|c|c|c|c|c|c|c|c|c|c|}
\hline \multirow{2}{*}{ Samples } & $\mathrm{T}_{0}\left({ }^{\circ} \mathrm{C}\right)$ & $\mathrm{T}_{\mathrm{p}}\left({ }^{\circ} \mathrm{C}\right)$ & $\Delta \mathrm{H}(\mathrm{J} / \mathrm{s})$ & $\mathrm{T}_{0}\left({ }^{\circ} \mathrm{C}\right)$ & $\mathrm{T}_{\mathrm{p}}\left({ }^{\circ} \mathrm{C}\right)$ & $\Delta \mathrm{H}(\mathrm{J} / \mathrm{s})$ & $\mathrm{T}_{0}\left({ }^{\circ} \mathrm{C}\right)$ & $\mathrm{T}_{\mathrm{p}}\left({ }^{\circ} \mathrm{C}\right)$ & $\Delta \mathrm{H}(\mathrm{J} / \mathrm{s})$ \\
\hline & \multicolumn{3}{|c|}{ After preparation } & \multicolumn{3}{|c|}{ After 8 months of storage } & \multicolumn{3}{|c|}{ After 16 months of storage } \\
\hline Raspberry puree & $-7.34 \pm 0.15^{c}$ & $-7.59 \pm 1.31^{\mathrm{c}}$ & $231.37 \pm 0.66^{b}$ & & & & & & \\
\hline$S$ & $-18.20 \pm 0.43^{b}$ & $-17.43 \pm 0.88^{b}$ & $196.36 \pm 1.27^{\mathrm{c}}$ & $-22.16 \pm 0.45^{a}$ & $-22.80 \pm 1.67^{a}$ & & $-21.35 \pm 1.02^{\mathrm{a}}$ & $-20.59 \pm 1.19^{a}$ & $106.24 \pm 1.26^{\mathrm{a}}$ \\
\hline $\mathrm{S}+\mathrm{F}$ & $-19.28 \pm 1.79^{\mathrm{a}, \mathrm{b}}$ & $-19.11 \pm 1.30^{\mathrm{a}, \mathrm{b}}$ & $118.06 \pm 0.84^{\mathrm{a}}$ & $-22.97 \pm 0.82^{\mathrm{a}}$ & $-23.26 \pm 0.21^{\mathrm{a}}$ & $103.48 \pm 0.59^{\mathrm{a}}$ & $-20.94 \pm 1.20^{\mathrm{a}}$ & $-20.80 \pm 1.39^{a}$ & $110.10 \pm 1.77^{\mathrm{b}}$ \\
\hline $\mathrm{S}+\mathrm{T}$ & $-20.19 \pm 0.65^{a}$ & $-19.17 \pm 0.38^{a}$ & $120.95 \pm 0.93^{\mathrm{a}}$ & $-23.06 \pm 0.58^{a}$ & $-22.83 \pm 1.34^{\mathrm{a}}$ & $104.64 \pm 0.91^{\mathrm{a}}$ & $-21.03 \pm 0.80^{\mathrm{a}}$ & $-19.47 \pm 0.73^{a}$ & $116.91 \pm 0.50^{c}$ \\
\hline $\mathrm{S}+\mathrm{TMS}$ & $-19.04 \pm 0.99^{\mathrm{a}, \mathrm{b}}$ & $-18.01 \pm 0.34^{\mathrm{b}, \mathrm{c}}$ & $124.32 \pm 0.59^{c}$ & $-23.05 \pm 0.77^{\mathrm{a}}$ & & & & $-21.81 \pm 0.29^{\mathrm{a}, \mathrm{b}}$ & $107.54 \pm 0.99^{\mathrm{a}, \mathrm{b}}$ \\
\hline $\mathrm{S}+\mathrm{WMMS}$ & $-19.61 \pm 0.48^{a}$ & $-18.15 \pm 1.08^{b}$ & $114.85 \pm 0.91^{\mathrm{b}}$ & $-23.87 \pm 0.62^{\mathrm{a}}$ & $-23.16 \pm 1.37^{\mathrm{a}, \mathrm{b}}$ & & $-21.72 \pm 0.78^{b}$ & $-21.27 \pm 1.41^{\mathrm{b}, \mathrm{c}}$ & $101.83 \pm 1.18^{\mathrm{a}}$ \\
\hline $\mathrm{S}+\mathrm{F}+\mathrm{TMS}$ & $-19.83 \pm 0.61^{a}$ & $-19.89 \pm 0.25^{a}$ & $117.99 \pm 0.94^{\mathrm{b}}$ & $-22.77 \pm 1.32^{\mathrm{a}}$ & $-22.48 \pm 0.40^{\mathrm{b}, \mathrm{c}}$ & $100.61 \pm 1.06^{\mathrm{a}, \mathrm{c}}$ & $-23.77 \pm 0.14^{\mathrm{a}}$ & $-23.12 \pm 1.02^{\mathrm{a}}$ & $104.19 \pm 0.54^{\mathrm{a}}$ \\
\hline $\mathrm{S}+\mathrm{F}+\mathrm{WMMS}$ & $-20.19 \pm 0.73^{\mathrm{a}}$ & $-19.93 \pm 0.49^{a}$ & $108.17 \pm 1.15^{\mathrm{a}}$ & $-23.85 \pm 1.04^{\mathrm{a}}$ & $-24.68 \pm 0.37^{\mathrm{a}}$ & $93.75 \pm 3.12^{\mathrm{a}}$ & $-24.41 \pm 0.90^{\mathrm{a}}$ & $-23.51 \pm 1.49^{\mathrm{a}}$ & $100.92 \pm 0.24^{\mathrm{a}}$ \\
\hline $\mathrm{S}+\mathrm{T}+\mathrm{TMS}$ & $-18.03 \pm 0.51^{b}$ & $-17.06 \pm 0.34^{\mathrm{c}, \mathrm{d}}$ & $125.99 \pm 1.85^{\mathrm{c}}$ & $-21.25 \pm 0.12^{b}$ & $-20.14 \pm 0.47^{d}$ & & $-21.42 \pm 1.07^{b}$ & $-20.03 \pm 0.04^{c}$ & $113.35 \pm 1.41^{\mathrm{b}}$ \\
\hline $\mathrm{S}+\mathrm{T}+\mathrm{WMMS}$ & $-19.04 \pm 0.78^{\mathrm{a}, \mathrm{b}}$ & $-17.58 \pm 0.19^{\mathrm{b}, \mathrm{d}}$ & $125.43 \pm 1.18^{c}$ & $-20.83 \pm 0.01^{\mathrm{b}}$ & $-19.82 \pm 0.13^{\mathrm{d}}$ & $104.82 \pm 0.47^{\mathrm{b}, \mathrm{c}, \mathrm{d}}$ & $-22.64 \pm 0.40^{\mathrm{a}, \mathrm{b}}$ & $-21.06 \pm 0.40^{c}$ & $112.63 \pm 1.98^{\mathrm{b}}$ \\
\hline $\mathrm{S}+\mathrm{KG}$ & $-18.12 \pm 0.75^{a}$ & $-16.26 \pm 0.70^{c}$ & $122.49 \pm 0.36^{\mathrm{c}}$ & $-21.91 \pm 0.26^{\mathrm{b}}$ & $-21.85 \pm 0.65^{\mathrm{a}, \mathrm{b}}$ & $102.93 \pm 0.38^{\mathrm{a}, \mathrm{b}}$ & $-19.17 \pm 1.36^{c}$ & $-17.89 \pm 1.24^{\mathrm{d}}$ & $114.15 \pm 0.77^{b}$ \\
\hline $\mathrm{S}+\mathrm{GG}$ & $-18.32 \pm 1.55^{\mathrm{a}, \mathrm{b}}$ & $-16.89 \pm 1.36^{b, c}$ & $129.20 \pm 0.46^{d}$ & $-21.19 \pm 1.03^{\mathrm{b}, \mathrm{c}}$ & $-21.07 \pm 0.29^{b}$ & $107.67 \pm 0.94^{d}$ & $-19.54 \pm 0.16^{c}$ & $-17.65 \pm 1.31^{\mathrm{d}}$ & $123.77 \pm 1.30^{c}$ \\
\hline $\mathrm{S}+\mathrm{F}+\mathrm{KG}$ & $-20.31 \pm 1.74^{\mathrm{a}}$ & $-21.25 \pm 1.09^{\mathrm{a}}$ & $101.76 \pm 1.59^{a}$ & $-23.78 \pm 0.52^{\mathrm{a}}$ & $-23.01 \pm 1.06^{\mathrm{a}}$ & $101.73 \pm 0.89^{\mathrm{a}}$ & $-23.26 \pm 0.30^{\mathrm{a}}$ & $-21.89 \pm 0.54^{\mathrm{a}}$ & $107.11 \pm 1.02^{\mathrm{a}}$ \\
\hline $\mathrm{S}+\mathrm{F}+\mathrm{GG}$ & $-19.18 \pm 1.28^{a}$ & $-18.29 \pm 0.28^{b}$ & $120.83 \pm 1.05^{b}$ & $-23.34 \pm 0.14^{a}$ & $-22.49 \pm 0.74^{a}$ & $105.25 \pm 0.79^{c}$ & $-19.82 \pm 0.89^{c}$ & $-18.79 \pm 0.75^{\mathrm{c}, \mathrm{d}}$ & $112.59 \pm 1.34^{b}$ \\
\hline $\mathrm{S}+\mathrm{T}+\mathrm{KG}$ & $-17.08 \pm 0.18^{\mathrm{b}, \mathrm{c}}$ & $-15.72 \pm 1.31^{\mathrm{c}}$ & $129.20 \pm 1.09^{\mathrm{d}, \mathrm{e}}$ & $-22.83 \pm 0.86^{\mathrm{a}, \mathrm{b}}$ & $-22.27 \pm 0.89^{a}$ & $104.59 \pm 1.53^{\mathrm{b}, \mathrm{c}}$ & $-22.30 \pm 1.05^{\mathrm{a}, \mathrm{b}}$ & $-20.48 \pm 1.70^{\mathrm{a}, \mathrm{b}}$ & $112.48 \pm 1.04^{\mathrm{b}}$ \\
\hline $\mathrm{S}+\mathrm{T}+\mathrm{GG}$ & $-16.92 \pm 0.93^{c}$ & $-15.61 \pm 0.25^{c}$ & $130.85 \pm 0.91^{\mathrm{e}}$ & $-19.95 \pm 0.29^{c}$ & $-18.94 \pm 0.11^{\mathrm{c}}$ & $111.18 \pm 0.53^{\mathrm{e}}$ & $-22.06 \pm 0.87^{b}$ & $-19.94 \pm 0.41^{b, c}$ & $113.70 \pm 0.89^{b}$ \\
\hline
\end{tabular}

Values are means \pm SD of triplicate. Values in the same column with different superscripts (a-f) are significantly different $(\mathrm{P}<0.05)$.

TABLE 7. Moisture content, unfreezable water content and thermal properties of raspberry cream fillings with sugars, modified starches and hydrocolloids addition.

\begin{tabular}{|c|c|c|c|c|c|}
\hline Sample & $\mathrm{MC}(\%)$ & $\omega_{\mathrm{g}}$ (g ufw / g dry solid) & $\mathrm{K}\left(\mathrm{JS} / \mathrm{m}^{\circ} \mathrm{C}\right)$ & $\mathrm{C}_{\mathrm{p}}\left(\mathrm{kJ} / \mathrm{kg}^{\circ} \mathrm{C}\right)$ & $\lambda(\mathrm{kJ} / \mathrm{kg})$ \\
\hline Raspberry puree & $92.16 \pm 1.46^{\mathrm{b}}$ & $2.34 \pm 0.53^{b}$ & $0.60 \pm 0.01^{\mathrm{b}}$ & $3.98 \pm 0.04^{\mathrm{b}}$ & $30874.7 \pm 87.49^{c}$ \\
\hline $\mathrm{S}$ & $63.81 \pm 0.62^{\mathrm{a}}$ & $0.67 \pm 0.07^{\mathrm{a}}$ & $0.46 \pm 0.01^{\mathrm{a}}$ & $3.27 \pm 0.02^{\mathrm{a}}$ & $21375.3 \pm 27.42^{\mathrm{b}}$ \\
\hline $\mathrm{S}+\mathrm{F}$ & $63.07 \pm 0.45^{\mathrm{a}}$ & $0.66 \pm 0.05^{\mathrm{a}}$ & $0.45 \pm 0.01^{\mathrm{a}}$ & $3.25 \pm 0.01^{\mathrm{a}}$ & $21127.4 \pm 15.08^{\mathrm{a}}$ \\
\hline$S+T$ & $63.10 \pm 0.96^{\mathrm{a}}$ & $0.65 \pm 0.07^{\mathrm{a}}$ & $0.46 \pm 0.01^{\mathrm{a}}$ & $3.25 \pm 0.02^{\mathrm{a}}$ & $21139.7 \pm 32.02^{\mathrm{a}}$ \\
\hline $\mathrm{S}+\mathrm{TMS}$ & $62.43 \pm 0.72^{\mathrm{b}, \mathrm{c}}$ & $0.68 \pm 0.05^{\mathrm{a}, \mathrm{b}, \mathrm{c}}$ & $0.45 \pm 0.01^{\mathrm{a}, \mathrm{b}}$ & $3.24 \pm 0.02^{\mathrm{b}}$ & $20912.9 \pm 24.72^{c}$ \\
\hline S+WMMS & $61.27 \pm 0.03^{\mathrm{a}}$ & $0.76 \pm 0.04^{c}$ & $0.44 \pm 0.01^{\mathrm{a}}$ & $3.21 \pm 0.01^{\mathrm{a}}$ & $20525.5 \pm 10.05^{\mathrm{a}}$ \\
\hline $\mathrm{S}+\mathrm{F}+\mathrm{TMS}$ & $61.65 \pm 0.12^{\mathrm{b}}$ & $0.70 \pm 0.01^{b}$ & $0.45 \pm 0.01^{\mathrm{a}, \mathrm{b}}$ & $3.22 \pm 0.01^{\mathrm{a}, \mathrm{b}}$ & $20653.9 \pm 39.09^{\mathrm{b}}$ \\
\hline $\mathrm{S}+\mathrm{F}+\mathrm{WMMS}$ & $61.09 \pm 0.25^{\mathrm{a}}$ & $0.78 \pm 0.03^{c}$ & $0.44 \pm 0.01^{\mathrm{a}}$ & $3.20 \pm 0.01^{\mathrm{a}}$ & $20467.4 \pm 85.36^{\mathrm{a}}$ \\
\hline $\mathrm{S}+\mathrm{T}+\mathrm{TMS}$ & $62.49 \pm 0.28^{c}$ & $0.65 \pm 0.02^{\mathrm{a}}$ & $0.46 \pm 0.01^{\mathrm{b}}$ & $3.24 \pm 0.01^{\mathrm{b}}$ & $20933.1 \pm 94.19^{c}$ \\
\hline $\mathrm{S}+\mathrm{T}+\mathrm{WMMS}$ & $62.35 \pm 0.87^{\mathrm{b}, \mathrm{c}}$ & $0.69 \pm 0.03^{\mathrm{a}, \mathrm{c}}$ & $0.46 \pm 0.01^{\mathrm{b}}$ & $3.23 \pm 0.02^{\mathrm{a}, \mathrm{b}}$ & $20887.3 \pm 91.31^{\mathrm{c}}$ \\
\hline $\mathrm{S}+\mathrm{KG}$ & $62.97 \pm 0.76^{\mathrm{b}, \mathrm{c}}$ & $0.68 \pm 0.07^{\mathrm{a}, \mathrm{b}}$ & $0.46 \pm 0.01^{\mathrm{a}}$ & $3.25 \pm 0.02^{\mathrm{b}, \mathrm{c}}$ & $21096.1 \pm 25.78^{\mathrm{d}}$ \\
\hline $\mathrm{S}+\mathrm{GG}$ & $63.51 \pm 0.15^{\mathrm{c}}$ & $0.73 \pm 0.03^{b}$ & $0.46 \pm 0.01^{\mathrm{a}}$ & $3.26 \pm 0.01^{\mathrm{c}}$ & $21277 \pm 48.81^{\mathrm{e}}$ \\
\hline $\mathrm{S}+\mathrm{F}+\mathrm{KG}$ & $61.48 \pm 0.42^{\mathrm{a}}$ & $0.84 \pm 0.03^{c}$ & $0.45 \pm 0.01^{\mathrm{a}}$ & $3.21 \pm 0.01^{\mathrm{a}}$ & $20596.9 \pm 41.85^{\mathrm{a}}$ \\
\hline $\mathrm{S}+\mathrm{F}+\mathrm{GG}$ & $61.78 \pm 0.08^{\mathrm{a}}$ & $0.73 \pm 0.06^{\mathrm{b}}$ & $0.45 \pm 0.01^{\mathrm{a}}$ & $3.20 \pm 0.01^{\mathrm{a}}$ & $20696.3 \pm 26.15^{\mathrm{b}}$ \\
\hline $\mathrm{S}+\mathrm{T}+\mathrm{KG}$ & $61.74 \pm 0.51^{\mathrm{a}, \mathrm{b}}$ & $0.70 \pm 0.05^{\mathrm{b}}$ & $0.45 \pm 0.01^{\mathrm{a}}$ & $3.20 \pm 0.01^{\mathrm{a}}$ & $20681.8 \pm 69.22^{\mathrm{a}, \mathrm{b}}$ \\
\hline $\mathrm{S}+\mathrm{T}+\mathrm{GG}$ & $62.39 \pm 0.18^{b}$ & $0.63 \pm 0.01^{\mathrm{a}}$ & $0.46 \pm 0.01^{\mathrm{a}}$ & $3.24 \pm 0.01^{\mathrm{b}}$ & $20900.7 \pm 58.67^{c}$ \\
\hline
\end{tabular}

$M C$ - moisture content; $\omega_{\mathrm{g}}-\mathrm{g}$ ufw / $\mathrm{g}$ of dry solid, ufw - unfreezable water; $K$ - thermal conductivity; $c_{\mathrm{p}}$ - specific heat capacity; $\lambda$ - latent heat of fusion. Values are means \pm SD of triplicate. Values in the same column with different superscripts $(\mathrm{a}-\mathrm{e})$ are significantly different $(\mathrm{P}<0.05)$. 
The thermal conductivity of the basic raspberry puree without additives was higher $\left(0.60 \mathrm{JS} / \mathrm{m}^{\circ} \mathrm{C}\right)$ than that of the cream fillings with additives $\left(0.44\right.$ to $0.46 \mathrm{JS} / \mathrm{m}{ }^{\circ} \mathrm{C}$ ) (Table 7). This may be due to a higher moisture content of raspberry puree compared with cream fillings with sugars, modified starches and hydrocolloids.

The values of latent heat of fusion ranged from 21,127.4 to $21,375.3 \mathrm{~kJ} / \mathrm{kg}$ for cream filling with the addition of sugars (Table 7). Basic raspberry puree without additives had the highest value $(30,874.4 \mathrm{~kJ} / \mathrm{kg})$, while values for cream fillings with sugars and modified starches addition ranged from $20,467.4$ to $20,933.1 \mathrm{~kJ} / \mathrm{kg}$ and for cream fillings with sugars and hydrocolloids addition ranged from 20,596.9 to $21,277 \mathrm{~kJ} / \mathrm{kg}$. The latent heat of fusion of the basic raspberry puree without additives was higher than that of the cream fillings with sugars, modified starches and hydrocolloids. This indicates that the amount of energy required for these purees and cream fillings to be frozen would be high.

\section{CONCLUSION}

After preparation and addition of different modified starches or hydrocolloids in combination with different sugar mixtures, an increased content of anthocyanins and total phenols was determined in raspberry cream fillings in comparison to the samples with sugar addition only. It was found that the addition of trehalose had a greater effect on colour retention, anthocyanins and total phenolics content compared to other added sugars. During storage of raspberry cream fillings for 8 and 16 months, the degradation of anthocyanins and total phenolic compounds occurred. The degradation was the highest in the samples with the addition of sucrose. The types of modified starches or hydrocolloids affected the retention of anthocyanins and total phenolics. The highest retention was observed in cream fillings with the addition of ST and WMMS or GG. Mix of ST and GG in combination was the best, because it gave the highest retention of phenols and anthocyanins.

Modified starches (TMS and WMMS) and hydrocolloids (KG and $\mathrm{GG}$ ), caused a decrease of freezing temperature in all cream fillings. The lower freezing temperatures were achieved upon the addition of WMMS in relation to TMS, and upon the addition of $\mathrm{KG}$ in relation to GG. In relation of modified starches to hydrocolloids, a slight decrease of freezing temperature was noticed upon the addition of WMMS compared to KG. Storage had an influence on cream fillings, too. All investigated samples had lower freezing temperatures after 8 and 16 months of storage compared to the initial samples. The addition of different combinations of sugars, modified starches and hydrocolloids in raspberry puree decreased the initial moisture content, specific heat capacity, thermal conductivity and latent heat of fusion of the basic puree. This indicates that the amount of energy required for these puree and cream fillings to be frozen would be high. Due to different influence of sugars, modified starches and hydrocolloids on thermophysical properties of raspberry cream fillings it is obvious that food formulation plays an important role in food product quality.

\section{RESEARCH FUNDING}

Research funding was supported by the Ministry of Science, Education and Sports of the Republic of Croatia.

\section{CONFLICT OF INTEREST}

None declared.

\section{REFERENCES}

1. Awika J.M., Behavior of 3-deoxyanthocyanidins in the presence of phenolic copigments. Food Res. Int., 2008, 41, 532-538.

2. Bakowska A., Kucharska A.Z., Oszmiański J., The effects of heating, UV irradiation, and storage on stability of the anthocyaninpolyphenol copigment complex. Food Chem., 2003, 81, 349-355.

3. Boulton R., The copigmentation of anthocyanins and its role in the color of red wine: A critical review. Am. J. Enol. Vitic., 2001, 52, 67-87.

4. Brouillard R., The in vivo expression of anthocyanin colour in plants. Phytochemistry, 1983, 22, 1311-1365.

5. Buffo R.A., Reineccius G.A., Oehlert G.W., Factors affecting the emulsifying and rheological properties of gum acacia in beverage emulsions. Food Hydrocolloid., 2001, 15, 53-66.

6. Clifford M.N., Anthocyanins - nature, occurrence and dietary burden. J. Sci. Food Agric., 2000, 80, 1063-1072.

7. Colaco C.A.L.S., Roser, B., Trehalose-a multifunctional additive for food preservation. 1995, in: Food Packaging and Preservation (ed. M. Mathlouthi). Blackie Professional, London, pp. 123-140.

8. Coultate T.P., Food: The Chemistry Of Its Components. 1989, Royal Society of Chemistry, London, pp. 186-203.

9. Dickerson R.W. Jr., Thermal-Properties of Foods in the Freezing Preservation of Foods. 1969, 4th Ed. (eds. O.K. Tresshor, W.B. van Arsdel, M.J. Copely, eds). Avi. Publ. Co. Inc., Westport Connecticut, pp. 26-51.

10. Duckworth R.B., Differential thermal analysis of frozen food systems. I. The determination of unfreezable water. J. Food Technol., 1971, 6, 317-327.

11. Fasina O.O., Thermophysical properties of sweet potato puree at freezing and refrigeration temperatures. Int. J. Food Prop., 2005, 8, 151-160.

12. Funami T., Kataoka Y., Omoto T., Goto Y., Asai I., Nishinari $\mathrm{K}$., Effects of non-ionic polysaccharides on the gelatinisation and retrogradation behaviour of wheat starch. Food Hydrocolloid., 2005, 19, 1-13.

13. Giusti M.M., Wrolstad R.E., Characterization and measurement of anthocyanins by UV-visible spectroscopy. 2001, in: Current Protocols in Food Analytical Chemistry (eds. R.E. Wrolstad, S.J. Schwartz). John Wiley \& Sons, New York, unit F1.2.1$-\mathrm{F} 1.2 .13$.

14. Hamdami N., Monteau J.Y., Le Bail A., Thermophysical properties evolution of French partly baked bread during freezing. Food Res. Int., 2004, 37, 703-713.

15. Hubbermann E.M., Stőckmann H., Schwarz K., Influence of different ingredients on the color stability of blackcurrant anthocyanins. 2002, in: Proceeding of 2nd Int. Congress on Pigments in Food (ed. J. Empis). Sociedade Portuguesa de Quimica Publ., 
Lissabon, Portugal, pp. 293-297. [http://www.foodtech.uni-kiel. de/download/Lissabon.PDF].

16. Hubbermann E.M., Heins A., Stőckmann H., Schwarz K., Influence of acids, salt, sugars and hydrocolloides on the colour stability of anthocyanins rich blackcurrant and elderberry concentrates. Eur. Food Res. Technol., 2006, 223, 83-90.

17. Kong J., Chia L., Goh N., Chia T., Brouillard R., Analysis and biological activities of anthocyanins. Phytochemistry, 2003, 64, 923-933.

18. Korus J., Juszczak L., Witczak M., Achremowicz B., Influence of selected hydrocolloids on triticale starch rheological properties. Int. J. Food Sci. Tech., 2004, 39, 641-652.

19. Lamb J., Experimental study. Influence of water on the physical properties of foods. Chem. Ind., 1976, 24, 1046-1048.

20. Levine H., Slade L., Influence of glassy and rubbery states on the thermal, mechanical and structural properties of doughs and baked products. 1989, in: Dough Rheology and Baked Product Texture, Theory and Practice (eds. H. Faridi, J.M. Faubion). AVI Pub. Co., New York, pp. 157-160.

21. Lewis M.J., Physical Properties Of Food And Food Processing Systems. 1987, Chi Chester Ellis Horwood Ltd, p. 108.

22. Lim H., Setser C.S., Paukstelis J.V., Sobczynska D., Nuclear magnetic resonance studies on wheat starch-sucrose water interactions with increasing temperature. Cereal Chem., 1992, 69, 382-386.

23. Mollov P., Mihalev K., Shikov V., Yoncheva N., Karagyozov V., Colour stability improvement of strawberry beverage by fortification with polyphenolic copigments naturally occurring in rose petals. Innov. Food Sci. Emerg. Technol., 2007, 8, 318-321.

24. Oszmiański J., Wojdyło A., Kolniak J., Effect of L-ascorbic acid, sugar, pectin and freeze-thaw treatment on polyphenol content of frozen strawberries. LWT - Food Sci. Technol., 2009, 42, 581-586.

25. Ough C.S., Amerine M.A., Phenolic Compounds. Methods for Analysis of Musts and Wines. 1988, John Wiley \& Sons Inc., New York, pp. 196-221.

26. Rahman M.S., Food Properties Handbook. 1995, CRC Press, Boca Raton FL, pp. 87-177.

27. Rein M., Copigmentation reactions and color stability of berry anthocyanins. 2005, PhD, Academic Dissertation, University of Helsinki, Department of Applied Chemistry and Microbiology, Food Chemistry Division. [http://helda.helsinki.fi/bitstream/ handle/10138/20822/copigmen.pdf? sequence $=1$ ].
28. Roos Y.H., Effect of moisture on the thermal behaviour of strawberries studied using differential scanning calorimetry. J. Food Sci., 1987, 52, 146-149.

29. Roos Y., Karel M., Kokini J.L., Glass transitions in low moisture and frozen foods: effects on shelf life and quality. Food Technol., 1996, 50, 95- 108.

30. Rossi A., Serraino I., Dugo P., Di Paola R., Mondello L., Genovese T., Morabito D., Dugo G., Sautebin L., Caputi A.P., Cuzzocrea S., Protective effects of anthocyanins from blackberry in a rat model of acute lung inflammation. Free Radic. Res., 2003, 37, 891-900.

31. Shimada K., Fujikawa K., Yahara K., Nakumara T., Antioxidative properties of xanthan on autoxidation of soybean oil in cyclodextrin emulsion. J. Agric. Food Chem., 1992, 40, 945-948.

32. Simpson K.L., Chemical changes in food during processing. 1985, in: Chemical Changes in Natural Food Pigments (eds. T. Richardson, J.W. Finley). NY: Van Nostrand Reinhold, New York, p.p. 153-184.

33. Sweat V.E., Thermal conductivity probe for small food samples. Trans. ASAE 17, 1974, 56-58.

34. Tocci A.M., Mascheroni R.H., Characteristics of differential scanning calorimetry determination of thermophysical properties of meats. LWT - Food Sci. Technol., 1998, 31, 418-426.

35. Tomasik P., Wang Y.J., Jane J.L., Complexes of starch with lowmolecular saccharides. Starch/Stärke, 1995, 47, 185-191.

36. Wang H., Zhang S., Chen G., Experimental study on the freezing characteristics of four kinds of vegetables. LWT - Food Sci. Technol., 2007, 40, 1112-1116.

37. Wang G., Thompson M.R., Liu Q., In situ kinetic study of solid-state crosslinking of potato starch. Starch, 2012, 64, 55-63.

38. Weast R.C., Astle M.J., Handbook of Chemistry and Physics. 1981, 63 rd ed. CRC Press: Boca Raton, Florida.

39. Wilska-Jeszka J., Korzuchowska A., Anthocyanins and chlorogenic acid copigmentation. Influence on the color of strawberry and chokeberry juices. Food Res. Technol., 1996, 203, 38-42.

40. Wrolstad R.E., Skrede G., Lea P., Enersen G., Influence of sugar on anthocyanin pigment stability in frozen strawberries. J. Food Sci., 1990, 55, 1064-1065, 1072.

41. Zhang Y., Vareed S.K., Nair M.G., Human tumor cell growth inhibition by non-toxic anthocyanidins, the pigments in fruit and vegetables. Life Sci., 2005, 76, 1465-1472.

Submitted: 19 May 2015. Revised: 7 December 2015 and 21 April 2016. Accepted: 29 April 2016. Published on-line: 5 October 2016. 